Provided for non-commercial research and education use. Not for reproduction, distribution or commercial use.

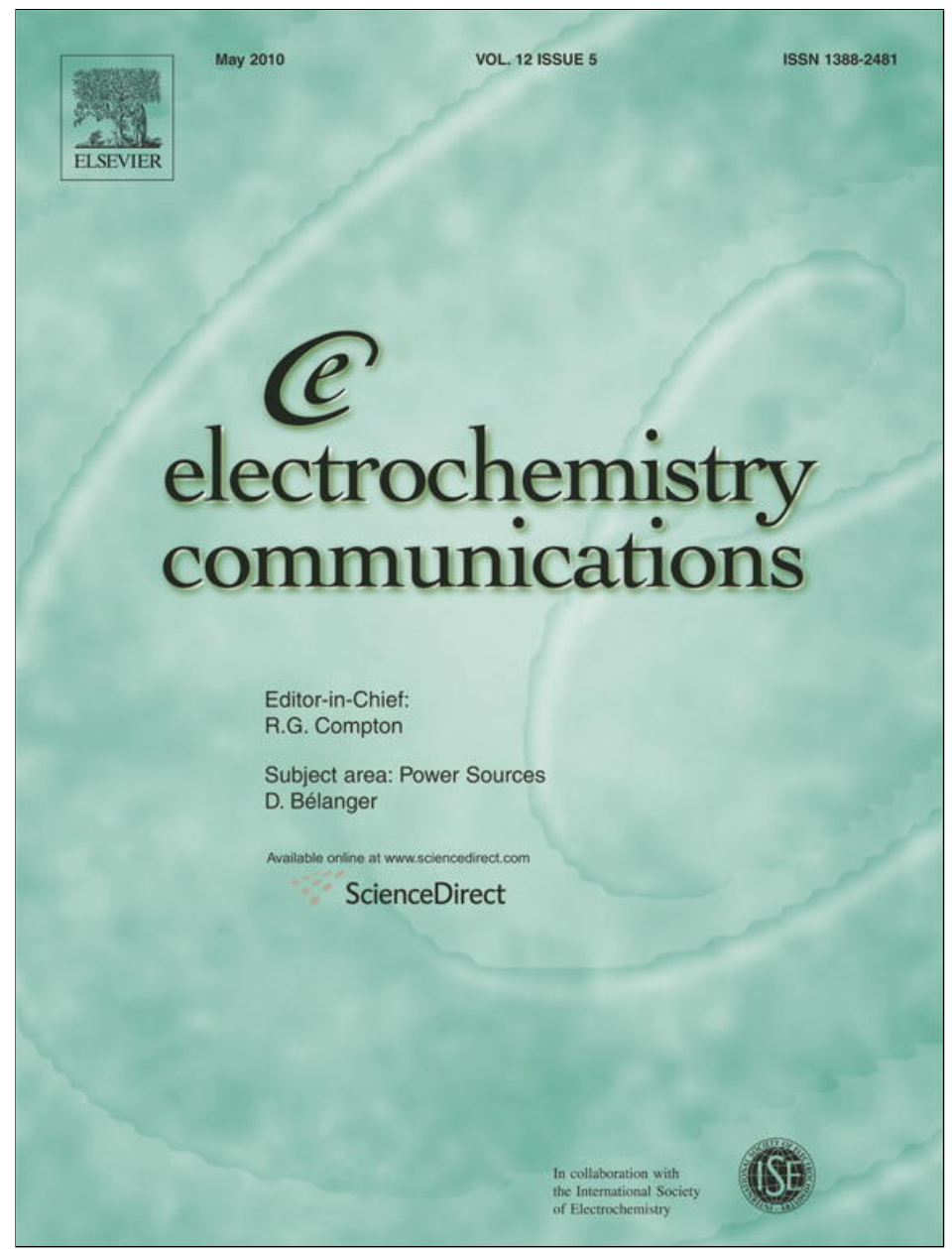

This article appeared in a journal published by Elsevier. The attached copy is furnished to the author for internal non-commercial research and education use, including for instruction at the authors institution and sharing with colleagues.

Other uses, including reproduction and distribution, or selling or licensing copies, or posting to personal, institutional or third party websites are prohibited.

In most cases authors are permitted to post their version of the article (e.g. in Word or Tex form) to their personal website or institutional repository. Authors requiring further information regarding Elsevier's archiving and manuscript policies are encouraged to visit:

http://www.elsevier.com/copyright 


\title{
Design of a bioelectrocatalytic electrode interface for oxygen reduction in biofuel cells based on a specifically adapted Os-complex containing redox polymer with entrapped Trametes hirsuta laccase
}

\author{
Yvonne Ackermann ${ }^{a}$, Dmitrii A. Guschin ${ }^{a}$, Kathrin Eckhard ${ }^{a}$, Sergey Shleev ${ }^{b}$, Wolfgang Schuhmann ${ }^{a}, *$ \\ a Analytische Chemie - Elektroanalytik E Sensorik, Ruhr-Universität Bochum, Universitätsstr. 150, D-44780 Bochum, Germany \\ b Biomedical Laboratory Science, Faculty of Health and Society, Malmö University, Södra Förstadsgatan 101, SE-20506 Malmö, Sweden
}

\section{A R T I C L E I N F O}

\section{Article history:}

Received 27 January 2010

Received in revised form 18 February 2010

Accepted 19 February 2010

Available online 1 March 2010

\section{Keywords:}

Laccase

Oxygen reduction

Electrodeposition polymer

Redox polymer

Biofuel cell

\begin{abstract}
A B S T R A C T
The design of the coordination shell of an Os-complex and its integration within an electrodeposition polymer enables fast electron transfer between an electrode and a polymer entrapped high-potential laccase from the basidiomycete Trametes hirsuta. The redox potential of the $\mathrm{Os}^{3+/ 2+}$-centre tethered to the polymer backbone $(+720 \mathrm{mV}$ vs. NHE) is perfectly matching the potential of the enzyme $(+780 \mathrm{mV}$ vs. NHE at pH 6.5). The laccase and the Os-complex modified anodic electrodeposition polymer were simultaneously precipitated on the surface of a glassy carbon electrode by means of a pH-shift to 2.5. The modified electrode was investigated with respect to biocatalytic $\mathrm{O}_{2}$ reduction to $\mathrm{H}_{2} \mathrm{O}$. The proposed modified electrode has potential applications as biofuel cell cathode.
\end{abstract}

(c) 2010 Elsevier B.V. All rights reserved.

\section{Introduction}

Efficient four-electron $\mathrm{O}_{2}$ bioelectroreduction at highly positive potentials using bilirubin oxidase [1-3] and laccases [4-9] "wired" with Os-complex modified polymers was described previously. Besides fundamental understanding of how $\mathrm{O}_{2}$ is bioelectrocatalytically reduced to $\mathrm{H}_{2} \mathrm{O}$ in nature avoiding intermediate formation of reactive oxygen species, applications in biosensors and membrane-less biofuel cells are of increasing importance [10-16]. Crucial for a membrane-less biofuel cell is that no cross reactivity between the cathode and anode reactions and moreover no reactions between the substrates used as fuels for the anode and cathode side occur. In addition, the biocatalysts have to be tightly immobilized on the electrode surface to prevent their mixing and depletion. Advantages arising from integrating the biocatalysts within three-dimensional Os-complex modified polymer layers are the significantly higher amount of the biocatalyst which is electrically connected via the polymer-bound redox centres to the electrode [17]. Recently, we have introduced a strategy for synthesizing Os-complex modified electrodeposition polymers [18-20]. Using a number of different monomers for the radical polymerization in combination with different Os-complexes,

\footnotetext{
* Corresponding author. Fax: + 492343214683.

E-mail address: wolfgang.schuhmann@rub.de (W. Schuhmann).
}

which are tethered to the polymer backbone, not only the formal potentials of the polymer-bound redox relays but also the physical properties (e.g. hydrophobicity, hydrophilicity, stability and permeability) can be tuned. This concept was already applied to the design of a biofuel cell cathode modified with bilirubin oxidase from Myrothecium verrucaria using an Os-complex modified anodic polymer [21]. Additionally, a complete membrane-less biofuel cell using cellobiose dehydrogenase from Trametes villosa at the anode and a high-potential laccase from Cerrena unicolor at the cathode was demonstrated [22].

Here, a new Os-complex modified anodic polymer with a formal potential specifically adjusted to the $\mathrm{T} 1 \mathrm{Cu}$-site of a high-potential laccase from the basidiomycete Trametes hirsuta is proposed. The enzyme is active and stable even at acidic conditions [23] and the potential of its $\mathrm{T} 1$ site is $780 \mathrm{mV}$ vs. NHE at $\mathrm{pH} 6.5$ [24]. The Oscomplex modified anodic electrodeposition polymer shows a $\mathrm{pH}-$ independent redox potential of $720 \mathrm{mV}$ vs. NHE, which is optimal to "wire" high-potential laccases from different origins [24,25].

\section{Experimental}

\subsection{Materials}

$\mathrm{K}_{2} \mathrm{HPO}_{4}, \mathrm{NaOH}, \mathrm{K}_{4}\left[\mathrm{Fe}(\mathrm{CN})_{6}\right]$ and citric acid were from Merck. Azoisobutyronitrile (98\%), anhydrous acrylic acid, triethylamine 
$\left(\mathrm{NEt}_{3}, 99 \%\right)$, and n-butyl acrylate were from Fluka. 2-pyridinecarboxyaldehyde (99\%), 2,2́-bipyridyl (99\%), glyoxal (40\% solution in water), and $\mathrm{K}_{2} \mathrm{OsCl}_{6}$ were obtained from Acros. $\mathrm{NaH}$ (95\%) was from Aldrich and acryloyl chloride (96\%) from Sigma-Aldrich. Isopropanol, ethanol, benzene, chloroform, $\mathrm{NH}_{4} \mathrm{OH}, \mathrm{Na}_{2} \mathrm{CO}_{3}, \mathrm{KOH}$, and $\mathrm{KCl}$ were from J.T. Baker. 2-chloroethanol (99\%) and $\mathrm{Na}_{2} \mathrm{SO}_{4}$ were from Riedelde-Haen. Osmium-bis-N,N-(2,2'-bipyridil)-dichloride and (2-pyridyl) imidazole were synthesised according to $[26,27]$.

\subsection{Instrumentation}

${ }^{1} \mathrm{H}$ NMR spectra were recorded on a Bruker DPX200 spectrometer in Methanol-D4 and evaluated using the MestRec Lite4.59 software. Chemical shifts in ppm $(\delta)$ were referenced to the residual solvent signal. A gas chromatograph (HP5890; Hewlett-Packard) connected with a mass selective detector (HP5970) using a (30 m length, $0.25 \mathrm{~mm}$ internal diameter, $0.25 \mu \mathrm{m}$ film thickness) DBxLB-mittel Polar $8-12 \%$ diphenylpolysiloxane capillary column at an oven temperature program of $60{ }^{\circ} \mathrm{C}$ for $2 \mathrm{~min}$, increasing to $300{ }^{\circ} \mathrm{C}$ at a rate of $15^{\circ} \mathrm{C} \mathrm{min}-1,300^{\circ} \mathrm{C}$ for 3 min was used with He as carrier gas at a flow rate of $1 \mathrm{ml} \mathrm{min}^{-1}$ and a split ratio of $1 / 90$. The injector and detector temperature was $250^{\circ} \mathrm{C}$. Particle size distribution of the electrodeposition paint was measured by dynamic light scattering (DLS) using a particle sizer (Malvern).

Glassy carbon rods ( $\varnothing 1.05 \mathrm{~mm}$, HTW) melted in glass capillaries (Hilgenberg) were used as working electrodes. The electrodes were cleaned by polishing with a fine emery paper (Tufback Durite, P1200), $3.0 \mu \mathrm{m}$ diamond suspension, followed by a $1.0 \mu \mathrm{m}$ and $0.3 \mu \mathrm{m}$ alumina paste (LECO). The electrodes were sonicated between and after polishing for $10 \mathrm{~min}$ in water.

Cyclic voltammograms of the laccase/redox polymer modified electrodes and differential pulse voltammograms (DPV) of the redox polymer solution were recorded using a three-electrode system connected to a PGSTAT12 potentiostat (Eco Chemie). All potentials were recalculated to the normal hydrogen electrode (NHE).

\subsection{Os-complex modified electrodeposition polymer}

\subsubsection{Synthesis of 2-(2-pyridin-2-yl-1H-imidazol-1-yl)ethanol (PyImEA)}

$21.9 \mathrm{~g}$ ( $151 \mathrm{mmol}$ ) of (2-pyridyl)imidazole in $80 \mathrm{ml}$ ethanol were added to a solution prepared from $3.76 \mathrm{~g}(157 \mathrm{mmol}) \mathrm{NaH}$ in $250 \mathrm{ml}$ ethanol. The reaction mixture was heated at $65^{\circ} \mathrm{C}$ for $1.5 \mathrm{~h}$ and a solution of $12.2 \mathrm{~g}$ ( $152 \mathrm{mmol}$ ) 2-chloroethanol in $20 \mathrm{ml}$ ethanol was added drop-wise. After $12 \mathrm{~h}$ heating at $65^{\circ} \mathrm{C}$ the precipitated $\mathrm{NaCl}$ was filtered off and the solvent was evaporated. The structure was confirmed by ${ }^{1} \mathrm{H}$ NMR and GC/MS.

\subsubsection{Synthesis of 2-(2-pyridin-2-yl-1H-imidazol-1-yl)ethyl acrylate}

$\mathrm{N}$-1-hydroxyethyl-(2-pyridyl)imidazole was dissolved in $200 \mathrm{ml}$ $\mathrm{CHCl}_{3}$. $14.2 \mathrm{~g}(157 \mathrm{mmol})$ acryloyl chloride in $20 \mathrm{ml} \mathrm{CHCl}$ were slowly added at $2-3{ }^{\circ} \mathrm{C}$. After $30 \mathrm{~min} 15.3 \mathrm{~g}(151 \mathrm{mmol})$ triethylamine in $40 \mathrm{ml}$ ethanol was added drop-wise under continuous stirring. The reaction was kept $2-3^{\circ} \mathrm{C}$ for $1 \mathrm{~h}$ and then stirred another $10 \mathrm{~h}$ at RT. The reaction mixture was washed with $150 \mathrm{ml}$ saturated $\mathrm{Na}_{2} \mathrm{CO}_{3}$ solution, 3 times with $150 \mathrm{ml}$ water, dried over $\mathrm{Na}_{2} \mathrm{SO}_{4}$ before the solvent was evaporated. The structure was confirmed by ${ }^{1} \mathrm{H}$ NMR.

2.3.3. Synthesis of poly(co-(2-butylcarboxylatoethylene)co-(2-(2-pyridin-2-yl-imidazol-1-yl) ethylcarboxylatoethylene)co-(carboxylatoethylene))

The polymerization was carried out as described previously [19,28]. $200 \mu \mathrm{L}$ azoisobutyronitrile (12.5\% in benzene) were added to a mixture of $500 \mu \mathrm{l}(1.9 \mathrm{mmol})$ of 2-((2-pyridyl)imidazolyl)ethyl acrylate, $500 \mu \mathrm{l}(7.3 \mathrm{mmol})$ of acrylic acid and $2000 \mu \mathrm{l}(14 \mathrm{mmol})$ of butyl acrylate. The copolymerization was initiated by heating the mixture at $90{ }^{\circ} \mathrm{C}$ for $5 \mathrm{~h}$. The copolymer was dissolved in $5 \mathrm{ml}$ methanol and neutralized with $10 \mathrm{M} \mathrm{KOH}(190 \mu \mathrm{L})$. The copolymer composition was determined by regressions analysis of the NMR-data to be ca. $71 \%$ butyl acrylate, $22 \%$ acrylic acid and 7\% PyImEA (mol\%).

\subsubsection{Synthesis of poly-(co-(2-(2-pyridyl-kN)imidazolyl-kN))-bis-}

(2,2'-bipyridyl-k2N, $\left.N^{\prime}\right)$-dichlorido-osmium(II)-

ethylcarboxylatethylene)-co-(carboxylatoethylene))-co-

(2-butylcarboxylatoethylene)))

$7 \mathrm{mg}$ of osmium-bis-(2,2'-bipyridil)-dichloride was added to $1.517 \mathrm{~g}$ of the copolymer solution. The reaction mixture was heated to $90{ }^{\circ} \mathrm{C}$ and stirred for $72 \mathrm{~h}$. Then methanol was slowly replaced by water. The mixture was continuously stirred for $24 \mathrm{~h}$ to form a stable Os-complex modified polymer suspension with a solid content of ca. $10 \%$. The redox properties of the resulting reaction mixture were investigated by means of DPV. The major part is directly reacting via an exchange of both labile chloro ligands to the envisaged product. A small fraction of the Os-complex is bound via an exchange of one chloro ligand (redox potential about $280 \mathrm{mV}$ ). Particle size from DLS: $193.4 \mathrm{~nm}$ (z-average).

\subsection{Isolation and purification of laccase}

The basidiomycete $T$. hirsuta, strain $T$. hirsuta 56 , was obtained from the laboratory collection of the State Research Institute of Protein Biosynthesis (Moscow). The extracellular laccase was isolated from the culture media and purified to homogeneity following [24]. The enzyme homogeneity was confirmed by HPLC and SDS-PAGE. The laccase preparation $\left(12.5 \mathrm{mg} \mathrm{ml}^{-1}, 315 \mathrm{U} \mathrm{mg}^{-1}\right)$ was stored in $50 \mathrm{mM}$ phosphate buffer $\mathrm{pH} 6.5$, at $-18^{\circ} \mathrm{C}$. The laccase concentration was measured spectrophotometrically at $228.5 \mathrm{~nm}$ and $234.5 \mathrm{~nm}$ using BSA as standard [29].

\subsection{Laccase assay and kinetic studies}

The dependence of laccase activity on the $\mathrm{pH}$-value in homogeneous solution was determined by estimation of the initial rates of $\mathrm{O}_{2}$ consumption using a Clark oxygen electrode in a sealed cell at $25^{\circ} \mathrm{C}$ with constant stirring. An appropriate concentration of $\mathrm{K}_{4}\left[\mathrm{Fe}(\mathrm{CN})_{6}\right]$ was used in order to ensure a measurable linear rate for the first $40 \mathrm{~s}$ after addition of the laccase preparation. The concentration of $\mathrm{O}_{2}$ was assumed to be $260 \mu \mathrm{M}$ in air-saturated solution. Bioelectrocatalytic activity was determined from the $\mathrm{O}_{2}$ reduction current of the laccase/ Os-polymer modified electrode at a potential of $350 \mathrm{mV}$ vs. NHE.

\subsection{Fabrication of modified bioelectrodes}

Mixtures of the laccase and the Os-complex modified polymer with compositions of pure enzyme, pure Os-complex modified polymer and a polymer-to-enzyme ratio of 1:1 were prepared using the $T$. hirsuta laccase preparation $\left(12.5 \mathrm{mg} \mathrm{ml}^{-1}\right.$ in $50 \mathrm{mM}$ phosphate buffer, $\mathrm{pH}$ 6.5 ) and the Os-complex modified polymer (ca. $100 \mathrm{mg} \mathrm{ml}^{-1}$ in $\mathrm{H}_{2} \mathrm{O}$ ). For cyclic voltammetry $0.5 \mu$ of the mixtures were placed on a cleaned electrode surface. After $20 \mathrm{~min}$ drying in air the electrodes were immersed for $30 \mathrm{~s}$ into a $100 \mathrm{mM}$ phosphate/citrate buffer, $\mathrm{pH} 2.5$, for decreasing the solubility of the electrodeposition polymer by protonation.

\section{Results and discussion}

In order to precisely match the potential of the T1 site of $T$. hirsuta laccase an Os-complex tethered to an anodic acrylate-based electrodeposition polymer was designed with a ligand sphere containing two 2,2'-bipyridyl groups and a bidentate pyridyl-imidazolyl ligand (Fig. 1). 


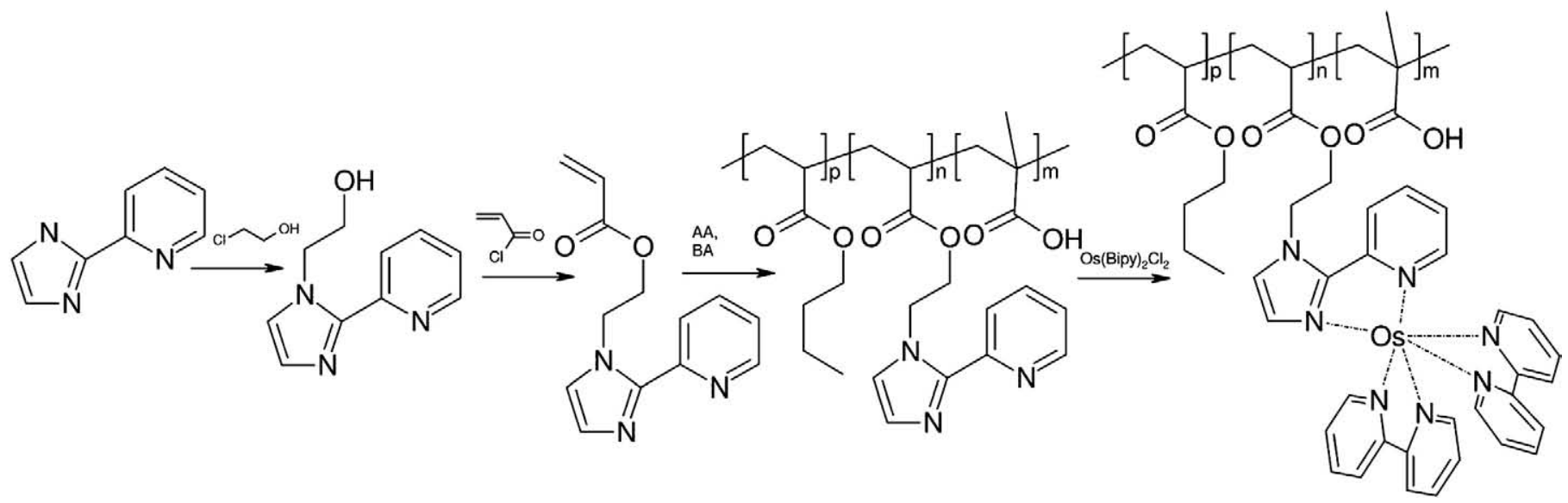

Fig. 1. Synthesis of the Os-complex modified electrodeposition paint.

The anodic shift of the redox potential upon exchanging the two labile chloro ligands against the polymer-tethered pyridyl-imidazolyl ligand is smaller then for a third bipyridyl group. A well-pronounced quasi-reversible redox conversion $\left(\Delta E_{\mathrm{p}} \approx 150 \mathrm{mV}\right)$ with a midpoint potential $\left(E_{\mathrm{mp}}\right)$ of about $740 \mathrm{mV}$ was determined by cyclic voltammetry. A second smaller redox wave was found at an $E_{\mathrm{mp}}$ of $280 \mathrm{mV}$ (Fig. 2). The redox process at $740 \mathrm{mV}$ corresponds to the redox couple of the (2-pyridyl-imidazolyl)-bis-bipyridyl-Os coordination sphere, whereas the low potential redox process is most likely due to an imidazolyl-chlorido-bis-bipyridyl-osmium complex which is formed as side product. During storage of a polymer-modified electrode almost all initially present imidazolyl-chlorido complexes transform to the high-potential 2-pyridyl-imidazolyl coordination. The redox transformation of the Os-complex modified polymer was found to be independent from the $\mathrm{O}_{2}$ concentration (Fig. 2) which was seen as a crucial prerequisite for the evaluation of the biocatalytic $\mathrm{O}_{2}$ reduction current in presence of both redox polymer and T. hirsuta laccase.

The bioelectrocatalytic activity of the laccase/Os-polymer-modified electrode with respect to $\mathrm{O}_{2}$ reduction was investigated by means of CV (Fig. 3). The electrode was modified with a solution containing equal amounts of the laccase and the redox polymer. A wellpronounced bioelectrocatalytic response at the redox potential of the polymer-bound Os-complex was obtained in air- and $\mathrm{O}_{2-}$ saturated phosphate/citrate buffers, $\mathrm{pH}$ 4.0. Obviously, T. hirsuta

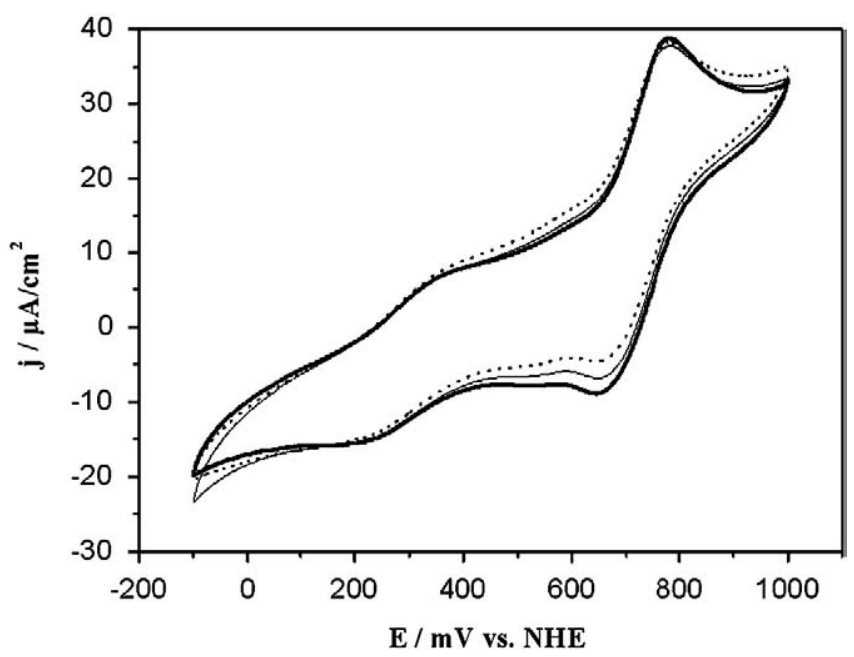

Fig. 2. Cyclic voltammograms of a glassy carbon electrode modified with the Oscomplex modified anodic electrodeposition polymer (argon, air and oxygen saturated buffers - dotted, solid and bold lines, respectively). Electrolyte: $100 \mathrm{mM}$ phosphate/ citrate buffer $\mathrm{pH} 4.0$; scan rate: $10 \mathrm{mV} \mathrm{s}^{-1}$. laccase is not denatured during its integration into the Os-polymer as well as during the polymer precipitation at $\mathrm{pH} 2.5$. As expected, neither the glassy carbon electrodes modified with either only electrodeposition paint or only laccase nor bare glassy carbon electrodes do not exhibit any electrocatalytic activity for $\mathrm{O}_{2}$ reduction in the investigated potential range (data not shown).

Cyclic voltammograms of the modified laccase/Os-polymer electrode (Fig. 3 ) in an air-saturated solution showed a diffusion-limited electrocatalytic reduction of $\mathrm{O}_{2}$ to $\mathrm{H}_{2} \mathrm{O}$ at a current density of $-130 \mu \mathrm{A} \mathrm{cm}^{-2}$ at about $+675 \mathrm{mV}$ vs. NHE. The decay of the catalytic current recorded in air-saturated solution indicates a mass-transport limited depletion of $\mathrm{O}_{2}$ in the enzyme/polymer film due to the fast turnover rate of the enzyme and rapid electron transfer between the Os-polymer and laccase. Moreover, voltammograms were dependent on stirring, which is also an indicator for mass-transport limitations within the polymer film. When pure $\mathrm{O}_{2}$ is purged into the measuring cell a limiting current density of $-325 \mu \mathrm{A} \mathrm{cm}{ }^{-2}$ is achieved. The experimentally obtained steady state $\mathrm{O}_{2}$ reduction current densities in air and oxygen saturated buffers $\left(-80 \mu \mathrm{A} \mathrm{cm}^{-2}\right.$ and $-325 \mu \mathrm{A} \mathrm{cm}^{-2}$, respectively) are in good agreement with theoretical diffusion-limited current densities assuming the angular frequency of laccase-modified electrodes to be approximately a radian per sec.

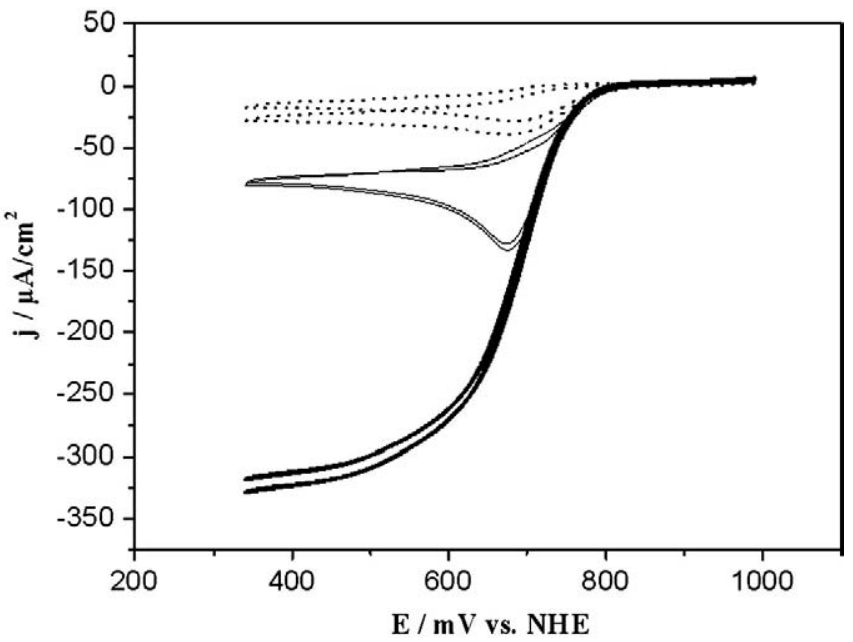

Fig. 3. Cyclic voltammograms displaying bioelectrocatalytic $\mathrm{O}_{2}$ reduction at the glassy carbon electrode modified with $T$. hirsuta laccase entrapped within in the Os-complex modified polymer matrix (argon, air and oxygen saturated buffers - dotted, solid and bold lines, respectively). Electrolyte: $100 \mathrm{mM}$ phosphate/citrate buffer $\mathrm{pH} 4.0$; scan rate: $5 \mathrm{mV} \mathrm{s}^{-1}$. 
Biocatalytic oxygen reduction started at a potential of about $800 \mathrm{mV}$ with a half-wave potential of about $750 \mathrm{mV}$ vs. NHE ( $\mathrm{pH} 4.0$ ). This value is in good agreement with the $E_{\mathrm{mp}}$-value of the Os-redox polymer (Fig. 2) suggesting that the polymer-tethered Os-centres function as electron donors for the enzyme and are hence communicating with the T1 Cu-site of the enzyme.

To further support the assumption that the Os-complex modified polymer is a pH-independent electron donor for the laccase the dependence of the electrocatalytic currents from the $\mathrm{pH}$ was investigated. The $\mathrm{pH}$ profiles for the electroreduction of $\mathrm{O}_{2}$ by $T$. hirsuta laccase incorporated into the redox polymer matrix perfectly coincide with the $\mathrm{pH}$ profiles for the oxidation of an "electron-noproton" laccase substrate (e.g. $\left[\mathrm{Fe}(\mathrm{CN})_{6}\right]^{3-/ 4-}$ ). The redox polymer obviously acts as electron donor while the protons necessary for the reduction of $\mathrm{O}_{2}$ to $\mathrm{H}_{2} \mathrm{O}$ are taken from the buffer solution.

\section{Conclusion}

A potential biofuel cell cathode has been developed based on $T$. hirsuta laccase/Os-modified redox polymer on a glassy carbon electrode. Successful synthesis of an Os-complex modified redox polymer with a redox potential well-adapted to the $\mathrm{T} 1 \mathrm{Cu}$-site of the laccase could be realized. Future work will aim on applications of the proposed bioelectrode architecture in biofuel cells namely by the optimization of the polymer-to-enzyme ratio, optimization of the Oscomplex loading at the polymer, the increase of the surface area of the electrode and the stability of the enzyme/polymer assembly.

\section{Acknowledgements}

The authors are grateful to the EU for financial support in the framework of the project "3D-Nanobiodevive" (NMP4-SL-2009229255). Y.A. thanks the Ruhr-University Research School (DFG GSC 98/1) for support. S.S. acknowledges financial support by the Swedish Research Council (2008-3713 and 2009-3266).

\section{References}

[1] N. Mano, H.H. Kim, A. Heller, J. Phys. Chem. B 106 (2002) 8842-8848.

[2] N. Mano, H.H. Kim, Y.C. Zhang A. Heller, J. Am. Chem. Soc. 124 (2002) 6480-6486.

[3] N. Mano, J.L. Fernandez, Y. Kim, W. Shin, A.J. Bard, A. Heller, J. Am. Chem. Soc. 125 (2003) 15290-15291.

[4] J.W. Gallaway, S.A. Barton, J. Electroanal. Chem. 626 (2009) 149-155.

[5] S.C. Barton, H.H. Kim, G. Binyamin, Y.C. Zhang, A. Heller, J. Phys. Chem. B 105 (2001) (1921) 11917-11921.

[6] F. Barriere, Y. Ferry, D. Rochefort, D. Leech, Electrochem. Commun. 6 (2004) 237-241.

[7] P. Kavanagh, P. Jenkins, D. Leech, Electrochem. Commun. 10 (2008) 970-972.

[8] N. Mano, V. Soukharev, A. Heller, J. Phys. Chem. B 110 (2006) 11180-11187.

[9] R. Szamocki, V. Flexer, L. Levin, F. Forchiasin, E.J. Calvo, Electrochim. Acta 54 (2009) 1970-1977.

[10] F. Daigle, F. Trudeau, G. Robinson, Smyth, D. Leech, Biosens. Bioelectron. 13 (1998) 417-425.

[11] Y. Ferry, D. Leech, Electroanalysis 17 (2005) 113-119.

[12] A. Heller, Phys. Chem. Chem. Phys. 6 (2004) 209-216.

[13] J.A. Cracknell, K.A. Vincent, F.A. Armstrong, Chem. Rev. 108 (2008) 2439-2461.

[14] F. Barriere, P. Kavanagh, D. Leech, Electrochim. Acta 51 (2006) 5187-5192.

[15] I. Willner, Y.M. Yan, B. Willner, R. Tel-Vered, Fuel Cells 9 (2009) 7-24.

[16] P. Kavanagh, S. Boland, P. Jenkins, D. Leech, Fuel Cells 9 (2009) 79-84.

[17] A. Heller, Curr. Opin. Chem. Biol. 10 (2006) 664-672.

[18] C. Kurzawa, A. Hengstenberg, W. Schuhmann, Anal. Chem. 74 (2002) 355-361.

[19] B. Ngounou, S. Neugebauer, A. Frodl, S. Reiter, W. Schuhmann, Electrochim. Acta 49 (2004) 3855-3863.

[20] B. Ngounou, E.H. Aliyev, D.A. Guschin, Y.M. Sultanov, A.A. Efendiev, W. Schuhmann, Bioelectrochem. 71 (2007) 81-90.

[21] K. Karnicka, K. Eckhard, D.A. Guschin, L. Stoica, P.J. Kulesza, W. Schuhmann, Electrochem. Commun. 9 (2007) 1998-2002.

[22] L. Stoica, N. Dimcheva, Y. Ackermann, K. Karnicka, D.A. Guschin, P.J. Kulesza, J. Rogalski, D. Haltrich, R. Ludwig, L. Gorton, W. Schuhmann, Fuel Cells 9 (2009) 53-62.

[23] I.S. Vasil'eva, O.V. Morozova, G.P. Shumakovich, S.V. Shleev, I.Y. Sakharov, A.I. Yaropolov, Synth. Met. 157 (2007) 684-689.

[24] S.V. Shleev, O. Morozova, O. Nikitina, E.S. Gorshina, T. Rusinova, V.A. Serezhenkov, D.S. Burbaev, I.G. Gazaryan, A.I. Yaropolov, Biochimie 86 (2004) 693-703.

[25] S. Shleev, J. Tkac, A. Christenson, T. Ruzgas, A.I. Yaropolov, J.W. Whittaker, L. Gorton, Biosens. Bioelectron. 20 (2005) 2517-2554.

[26] K. Habermuller, A. Ramanavicius, V. Laurinavicius, W. Schuhmann, Electroanalysis 12 (2000) 1383-1389.

[27] S.-M. Yue, H.-B. Xu, J.-F. Ma, Z.-M. Su, Y.-H. Kan, H.-J. Zhang, Polyhedron 25 (2006) 635-644.

[28] D.A. Guschin, H. Shkil, W. Schuhmann, Anal. Bioanal. Chem. 395 (2009) 1693-1706.

[29] B. Ehresman, P. Imbault, J.H. Weil, Anal. Biochem. 54 (1973) 454-463. 